\title{
THE IMPORTANT OF TOPONYM IN THE MIDDLE OF MAPS AND IMAGERY FOR DISASTER MANAGEMENT
}

\author{
A. P. Perdana ${ }^{a}, *$, E. Hendrayana ${ }^{a}$, W. E. Santoso ${ }^{\text {b }}$ \\ ${ }^{a}$ Center for Topographic Base Mapping, BAKOSURTANAL, Cibinong, Bogor, West Java Province, Indonesia - \\ ajiputrap@gmail.com, (aji.perdana, edwinh)@ bakosurtanal.go.id \\ ${ }^{\mathrm{b}}$ Toponym Expert, BAKOSURTANAL, Cibinong, Bogor, West Java Province, Indonesia - wides_bgr@ yahoo.com
}

ICA and TC IV/8 Maps, Imagery and Crowd Sourcing for Disaster Management

KEY WORDS: Maps, Imagery, Disaster Management, Toponym, Gazetteer

\begin{abstract}
:
Maps without toponym is blind maps, imagery without names in top of it is hard for us to understand for which location the imagery stand for. Place names should be verified and validated to maintain its unique, the consistency and accuracy also to understand the meaning behind the geographical names. In Indonesia, toponym is part of basic geospatial information that mentioned in Act Number 4 Year 2011 about Geospatial Information. According to Presidential Regulation Number 112 Year 2006 about National Team for Geographical Names Standardization mentioned that accurate information and data about the geographical names should be achieved and realizing the national gazetteer so there is a similarity of topographical names in Indonesia. Based on several disaster evidences in Indonesia, peoples are always looking for geographical names as the first key to enter relevant information. The accurate and consistent writing in geographical names play important roles in the maps and imagery. There is a need to build national gazetteer for disaster management and many other purposes because it is basic element for communication extensively in support social development, economic, conservation, and national infrastructure.
\end{abstract}

\section{INTRODUCTION}

\subsection{Background}

Recently maps and imagery is part of our life and the development of information and technology has brought new perspective in understanding our environment through the use of geospatial information. Now people can easily access and get geospatial information in maps form or imagery. Maps already used as tools in planning and management, in this case for disaster management.

The first question when disaster happen is where (location). Location is related to geographical position and name of place. When they have no exact latitude and longitude or not have information which number of topographic maps for the area where disaster happen and in other side the only information that they know is name of place. This is the important of toponym and gazetteer to solve it and connect or enter to related information they need.

Toponym is name of place in earth surface, while toponym as science is science about geographical names and toponym also the totality of place name in certain area (Santoso, 2006). Geographical names include all the names of natural and cultural phenomena, such as the names of mountains, hills, islands, bays, straits, village, sub district, district, provincial, bridges, dams, buildings, roads, etc. Geographical names which sometimes are called Place Names or Topographical Names, in Indonesia used "Topographical Names" (Perdana, et. al., 2011a). Toponym has become part of Indonesian topographical maps. Toponym is one of the layers in basic geospatial information according to Act Number 4 of Geospatial Information.

In maps, it can be seen that there are name of mountains, rivers, bay, administrative names, etc and maps without is blind. Not only maps that need geographical names or toponym, but the emerging of Google Earth and Bing Imagery in their sites, toponym is also included and gazetteer is become one of the geospatial information that used as the key for people searching place based on names. Imagery without names in top of it is hard for us to understand for which location the imagery stand for. Crowded sources related geographical names should controlled by names of authority organization.

Place names should be verified and validated to maintain its unique, the consistency and accuracy also to understand the meaning behind the geographical names (Santoso, $2006 \mathrm{~b}$; Mayasari, et. al., 2011). All geographical names with a variety of relevant information such as name, writing, pronunciation, and origin of language, history, and type of element, coordinates, site of administration, name and map number, status, accessibility, potency have been collected by BAKOSURTANAL in database of geographical names (PPDR, 2011). But, those data not yet validated totally due to a lot of information and need coordination among members of National Team for Geographical Names Standardization. Until now, features that have been verified by team are names of islands

\footnotetext{
* Corresponding author.
} 
and administrative names. For administrative names still not completed yet due to the absence of several sub district or district in validation process in the province level.

According to Presidential Regulation Number 112 Year 2006 about National Team for Geographical Names Standardization mentioned that accurate information and data about the geographical names should be achieved and realizing the national gazetteer so there is a similarity of topographical names in Indonesia.

Tsunami in Aceh and Nias 2004 was the greatest event of tsunami that hundreds thousands of people died and also cause environmental damage. Earthquake disaster in Yogyakarta and Central Java 2006 caused many people died. Eruption of Merapi Volcano happened in 2008, earthquake in West Sumatra Province year 2009. Then in the year of 2010, flash floods occurred in Wasior, earthquake and tsunami in Mentawai also the eruption of Merapi Volcano in Central Java and Yogyakarta (BNPB, 2011a; BNPB, 2011b; Kardono et.al., 2009). Based on several disaster evidences in Indonesia, peoples are always looking for geographical names as the first key to enter relevant information. Those disasters need geospatial information that consistence and accurate, especially one of the important things is geographical names (Perdana et.al, 2011a; Perdana et.al, 2011b).

The accurate and consistent writing in geographical names play important roles in the maps and imagery. There is a need to build national gazetteer for disaster management and many other purposes because it is basic element for communication extensively in support social development, economic, conservation, and national infrastructure.

This paper describes the important of geographic names or toponym in the middle maps and imagery for disaster management applications based on the current condition and future need in Indonesia facing disaster.

\subsection{Aims}

The aims of this research are building the same understanding on the need of accurate and consistent geographical names as part of basic geospatial information for supporting disaster management.

\subsection{Study Area}

Study area in this research is Negara Kesatuan Republik Indonesia (Figure 1) to depict and understand the current condition of toponym and the development of gazetteer nationally in term of geospatial information for disaster management. Indonesia is a country in South East Asia, located in equator line and among the continents of Asia and Australia as well as between the Pacific and Indian Ocean. Because it lies between two continents and two oceans, he is also known as Nusantara (Archipelagic State).

Indonesia has a lot of natural and disaster features and also has many local languages. People gave name of place with their local names to help them identify its location that is why we need to see in our preparation regarding geographical names to supporting geospatial information in disaster management at national scale. The uniqueness of natural and artificial geographical names as human way in identifying environment and makes it important as a reference in communication for disaster or regional management (Santoso, 2006a; Santoso, 2006b; Perdana et.al, 2011a).

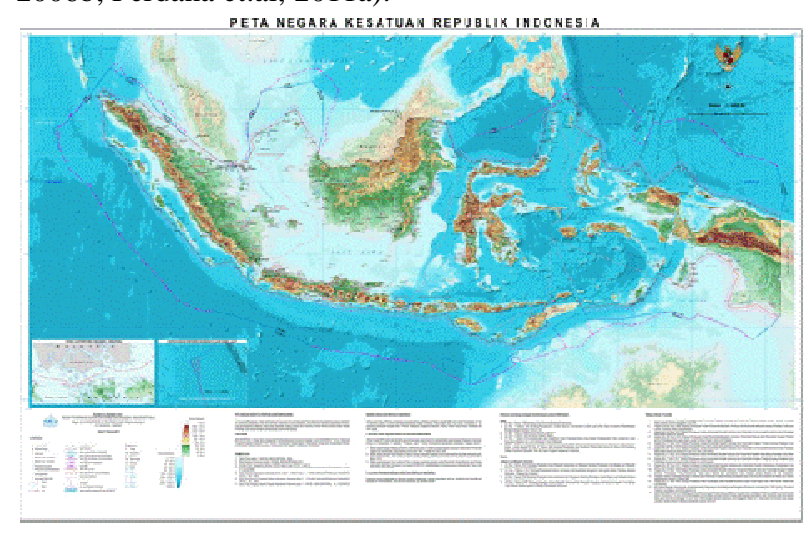

Figure 1. Study Area (Source: Peta Negara Kesatuan Republik Indonesia, (C BAKOSURTANAL (2010))

\section{DATA AND METHOD}

\subsection{Preparation}

This research start with literature study that consist of previous study, government laws, overview of existing disaster maps and geospatial information related to disaster. Such as collecting information from BAKOSURTANAL as government organization responsible for geospatial information coordinating, BNPB as national disaster agency in Indonesia, Universities that produced maps related disaster, NonGovernment Organization (either national or international that worked in Indonesia) and local people that faced or victim of disaster.

\subsection{Data Acquisition}

Maps and imagery to be compared was accessed from internet and also directly from the institution. Topographic base map and gazetteer data were acquired from Center for Topographic Base Mapping-BAKOSURTANAL as the key on how toponym should be processed into gazetteer to provide geospatial data for supporting disaster management. For better understanding on how toponym was extracted from the field and processed into gazetteer to be provided as one of the layers in topographic base map or basic geospatial information.

\subsection{Analysis}

This study analysis is based on comparison analysis from crowded sources of maps and images which use toponym or gazetteer as part of them. The purpose of the analysis is to reveal the need of accurate and consistent of toponym.

\section{RESULT AND DISCUSSION}

The result from this study is analysis of several maps and website related disaster management. 


\subsection{Maps and Imagery of Disaster}

Maps help people to understand their environment spatially. Many maps related disaster provided when disaster occurred and part of them also prepared as part of disaster risk reduction, but lack of them socialize to local government or local people. Toponym is one of the important layers presented in maps. Besides maps, recently when disaster happened many satellite images comes for free to be download and it can be found that name of place is not in correct writing and not accurate position.

Map prone disaster of Mt. Semeru provided by BNPB then to be used as one of the maps which use toponym in their disaster information. Comparison analysis was conducted with topographic map scale 1:25.000 to extract toponym information. Toponym from numbers of map sheets to be processed and built into gazetteer. Then, validated toponym is presented in Map of Disaster Prone Area of Mt. Semeru as can be seen in Figure 3.

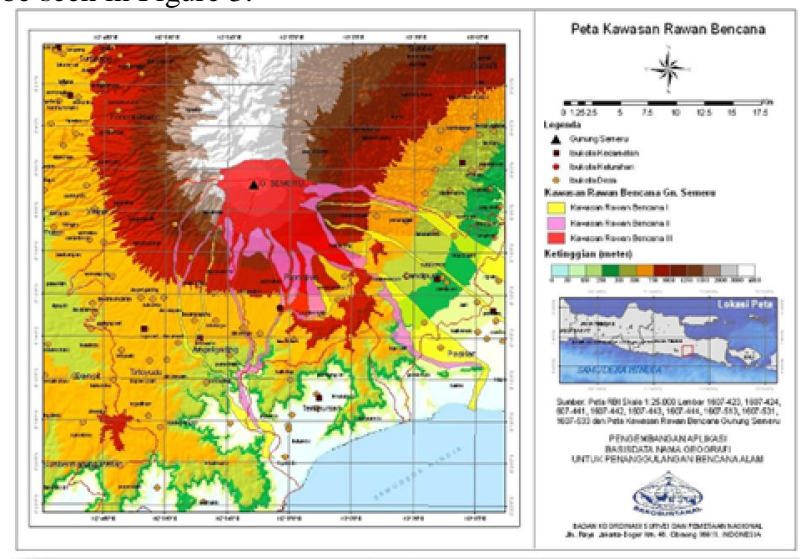

Figure 3. Map of Disaster Prone Area of Mt. Semeru with Geographical Names that have been verified

Field survey of geographical was done in Mt. Semeru to be compared also with toponym in Google Earth. As can be seen in Figure 4 there is several areas with incorrect administrative geographical names.

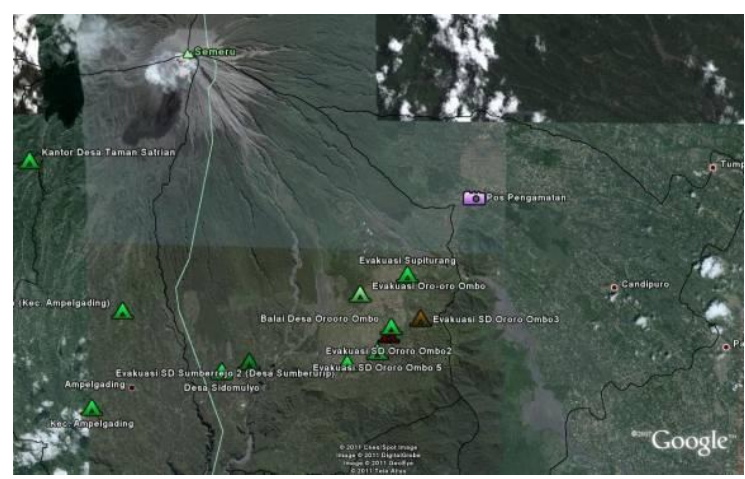

Figure 4. Image on Google Earth with toponym from Google and Field Survey

Based on the analysis, GeoNames website (geonames.org) is the complete gazetteer (Figure 5), even though source of toponym or name of place is not mentioned clearly. It can be said that this is not official information, but toponym from this website is valuable for us in order to understand name and location of places. Toponym from GeoNames is needs to be check carefully using the principle of toponym in accuration position and consistency in writing.

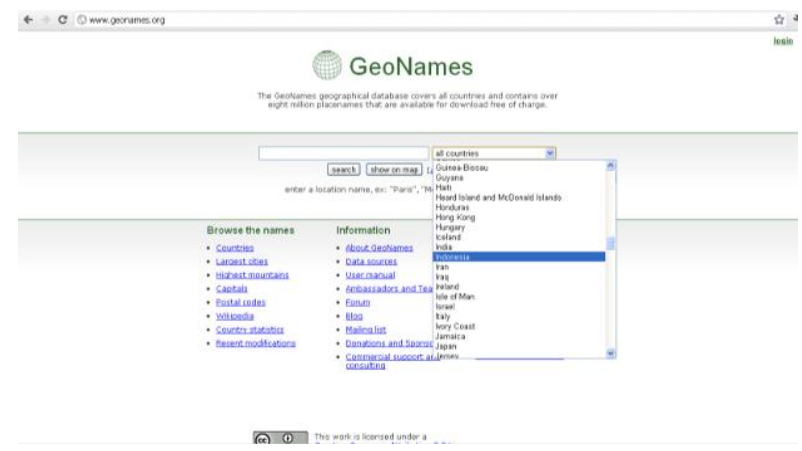

Figure 5. GeoNames website (geonames.org) provide gazetteer for the world

\subsection{Geospatial Information for Disaster in Web}

The development of geospatial information and technology has provides us with crowded data sources. Geospatial information can be accessible and downloadable freely. Recently, BAKOSURTANAL has launched Geospasial Untuk Negeri as geoportal in which people can see Indonesia contains of basic and thematic geospatial information. BNPB also has geospatial website which provide maps and WebGIS, but all of those website do not yet properly use gazetteer as part of their website for search or query based on name of place (Figure 6 and Figure 7).

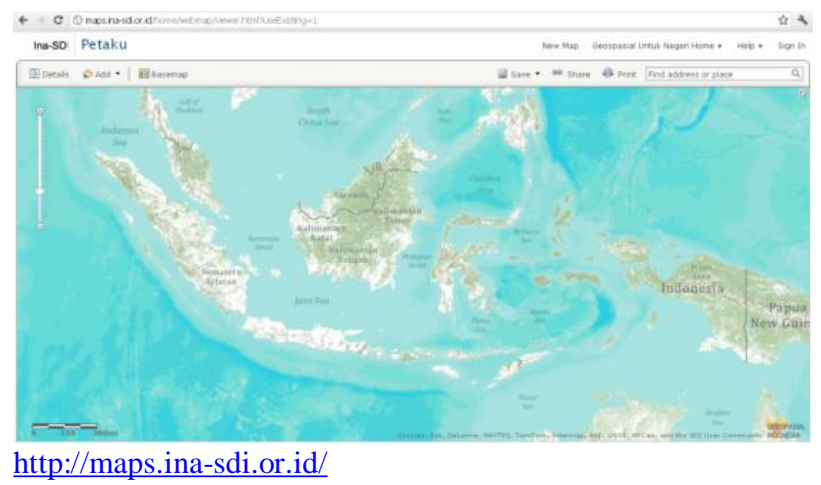

Figure 6. Geospasial Untuk Negeri (Indonesian Geoportal)

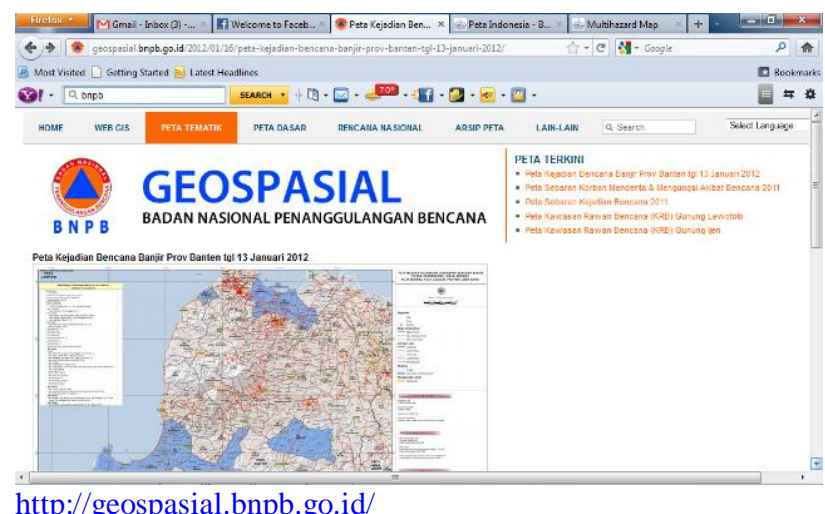

Figure 7. Geospasial BNPB (National Disaster Agency website) 


\subsection{Collection of Toponym, Building Gazetteer and Validation Geographical Names}

In order to provide the accurate and consistence toponym there are three main steps: data collecting, building gazetteer and verification or validation of toponym by National Team for Geographical Names Standardization. Figure 8 depict the step of building gazetteer to be used as accurate and consistent toponym.

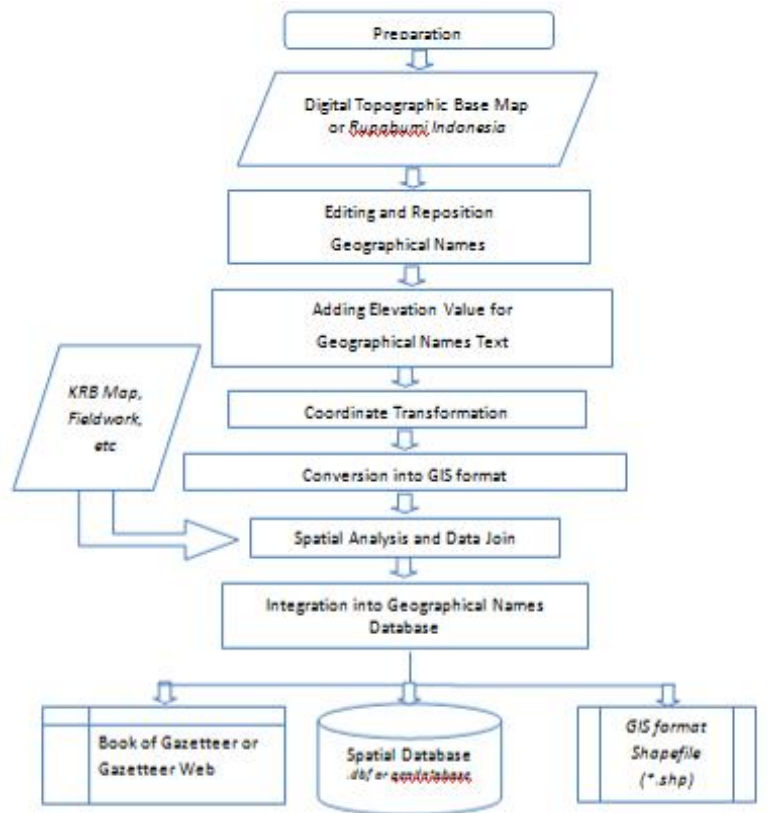

Figure 8. The step of building geographical names database (Source: Modified from KAKT, Pusat Pemetaan Dasar Rupabumi-BAKOSURTANAL)

\section{CONCLUSION}

Based on results and discussions above we may conclude that geographical names or topographic name as part of basic geospatial information according to Act Number 4 of Geospatial Information have an important role in disaster management. Verification and validation of geographical names include all the names of natural and cultural phenomena, such as the names of mountains, islands, village, sub district, district, provincial, buildings, roads, etc should be done before geographical names database is distributed for disaster management or many other purposes. Spatial analysis can be use for enhancing information that could be tied with geographical names.

Geographical names database with the final output in gazetteer format that can be accessed through web is challenging and can be part of an effort to realizing the national gazetteer so that there is a common understanding of the topographical names in Indonesia. The key of gazetteer is accurate and consistence geospatial information as basic element of communication for planning and management.

\section{REFERENCES}

BNPB, 2011a. "Laporan Utama: Lima Bencana Terbesar Tahun 2010," Gema BNPB Maret 2011 Volume 2 No.1, 4-6.
BNPB, 2011b. "Laporan Utama: Dari Wasior, Mentawai hingga Merapi," Gema BNPB Maret 2011 Volume 2 No.1, 716 (2011).

Government of Indonesia, 2008. Peraturan Presiden Nomor 112 Tahun 2006 tentang Tim Nasional Pembakuan Nama Rupabumi, Jakarta Pusat, Indonesia.

Government of Indonesia, 2008. Peraturan Menteri Dalam Negeri Nomor 39 Tahun 2008 tentang Pedoman Umum Pembakuan Nama Rupabumi, Jakarta Pusat, Indonesia.

Government of Indonesia, 2011. Undang-undang Nomor 4 Tahun 2011 tentang Informasi Geospasia, Jakarta, Indonesia.

Kardono, P., Hermana, Neulis, Z., Lestari, L., Sulistyowati, Maulidhini, N., and Pinuji, S.E., 2009. Data Bencana Indonesia Tahun 2009, Badan Nasional Penanggulangan Bencana, Jakarta, Indonesia.

Pusat Pemetaan Dasar Rupabumi BAKOSURTANAL, 2011. Penyusunan dan Pembentukan Basis Data Nama-Nama Unsur Rupabumi (Gasetir), Term of Reference Kerangka Acuan Kerja Teknis, Cibinong, Bogor, Indonesia.

Mayasari, R., Perdana, A.P., and Firdaus, W., 2011. "The Use of Topographic Map Scale 1:25.000 in Geographical Names Validation in West Java, Indonesia," 10th Annual Asian Conference \& Exhibition on Geospatial Information Technology \& Applications, ASIA GEOSPATIAL FORUM 'Geospatial Convergence-Paradigm for Future', 17-19 Oktober 2011, Hotel Mulia Senayan, Jakarta, Indonesia.

Perdana, A.P., Santoso, W.E., and Martha, S., 2011a. "Pentingnya Toponimi dalam Pengelolaan Wilayah dan Manajemen Bencana di Indonesia," The 2nd National Symposium on Geoinformation Science - 'Membangun Informasi Geospasial untuk Pengelolaan dan Pengembangan Wilayah', 27-28 Oktober 2011 Gedung PascaSarjana, Gadjah Mada University, Yogyakarta, Indonesia.

Perdana, A.P., Juniati, E., Mayasari, R., and Santoso, W.E., 2011b. "Peluang dan Tantangan dalam Penyusunan Basisdata Nama-nama Rupabumi (Gasetir) untuk Mendukung Pengelolaan Wilayah," The 2nd National Symposium on Geoinformation Science - 'Membangun Informasi Geospasial untuk Pengelolaan dan Pengembangan Wilayah', 27-28 Oktober 2011 Gedung PascaSarjana, Gadjah Mada University, Yogyakarta, Indonesia.

Santoso, W.E., 2006a. Pengantar Toponimi-Modul Pelatihan Jabatan Fungsional Surveyor Pemeta Tingkat Terampil dan Ahli,Balai Pendidikan dan Pelatihan Survey dan Pemetaan, BAKOSURTANAL, Cibinong, Bogor, Indonesia.

Santoso, W.E., 2006b. Inventarisasi dan Penyusunan Gasetir Odonim, Jurnal Ilmiah Geomatika 12(1). 
International Archives of the Photogrammetry, Remote Sensing and Spatial Information Sciences, Volume XXXIX-B4, 2012 XXII ISPRS Congress, 25 August - 01 September 2012, Melbourne, Australia

\section{ACKNOWLEDGEMENTS}

We would like to express our sincere thanks to The Head and colleagues of Center for Topographic Base MappingBAKOSURTANAL for supporting this research by providing basic geospatial information. Thanks also to National Team for the Standardization of Topographical Names. 